\title{
Figures and boxes
}

\section{FIGURES}

5.1 Philanthropic giving (cash and other property gifts) as a percentage of GDP 1995-2002 72

$\begin{array}{ll}5.2 \text { Civil society-state dichotomy } & 76\end{array}$

6.1 Community responses to the global economy 103

$\begin{array}{ll}6.2 \text { Modes of development } & 104\end{array}$

10.1 Typology of entrepreneurial behavior 200

12.1 The conceptual model of external and internal explanations of social ventures long-term survivability

\section{BOXES}

6.1 The characteristics of Aboriginal economic development 92

6.2 Osoyoos Indian Band goals 109

8.1 Requirements for reconceptualizing entrepreneurship in public affairs

8.2 Policy entrepreneurship: a reconceptualization of entrepreneurship in public affairs 
Gordon E. Shockley, Peter M. Frank, and Roger R. Stough - 9781848445154 Downloaded from PubFactory at 04/26/2023 04:37:11AM 